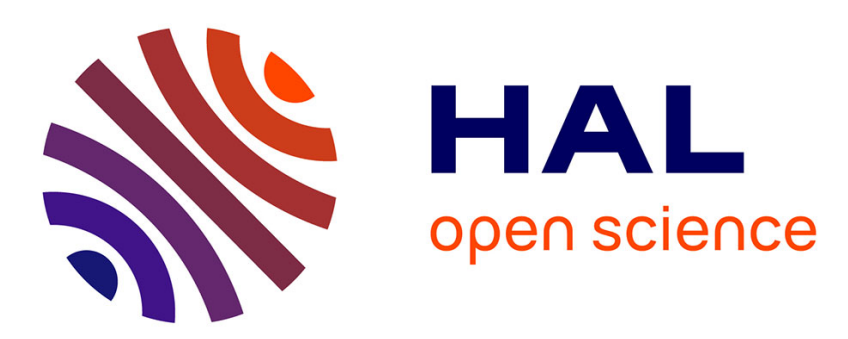

\title{
Plasticity of trophic interactions among sharks from the oceanic south-western Indian Ocean revealed by stable isotope and mercury analyses
}

Jeremy Kiszka, Aurore Aubail, Nigel E Hussey, Michael R Heithaus, Florence Caurant, Paco Bustamante

\section{To cite this version:}

Jeremy Kiszka, Aurore Aubail, Nigel E Hussey, Michael R Heithaus, Florence Caurant, et al.. Plasticity of trophic interactions among sharks from the oceanic south-western Indian Ocean revealed by stable isotope and mercury analyses. Deep Sea Research Part I: Oceanographic Research Papers, 2015, 96, pp.49 - 58. 10.1016/j.dsr.2014.11.006 . hal-01104575

\section{HAL Id: hal-01104575 \\ https://hal.science/hal-01104575}

Submitted on 17 Jan 2015

HAL is a multi-disciplinary open access archive for the deposit and dissemination of scientific research documents, whether they are published or not. The documents may come from teaching and research institutions in France or abroad, or from public or private research centers.
L'archive ouverte pluridisciplinaire HAL, est destinée au dépôt et à la diffusion de documents scientifiques de niveau recherche, publiés ou non, émanant des établissements d'enseignement et de recherche français ou étrangers, des laboratoires publics ou privés. 


\section{Plasticity of trophic interactions among sharks from the oceanic south-western Indian Ocean revealed by stable isotope and mercury analyses}

Jeremy J. Kiszka ${ }^{1,2}$, Aurore Aubail ${ }^{2}$, Nigel E. Hussey ${ }^{3}$, Michael R. Heithaus ${ }^{1}$, Florence Caurant ${ }^{2}$, Paco Bustamante ${ }^{2}$

${ }^{1}$ Marine Sciences Program, Department of Biological Sciences, Florida International University, 3000 NE $151^{\text {st }}$ Street, North Miami, Florida 33181, USA

${ }^{2}$ Littoral Environnement et Sociétés (LIENSs), UMR 7266 CNRS-Université de la Rochelle, Institut du Littoral et de l'Environnement, 2 rue Olympe de Gouges, 17000 La Rochelle, France

${ }^{3}$ Great Lakes Institute for Environmental Research, University of Windsor, 401 Sunset Avenue, ON, N9B 3P4, Canada

Corresponding author: Jeremy Kiszka

Marine Sciences Program, Department of Biological Sciences, Florida International University, 3000 NE $151^{\text {st }}$ Street, North Miami, Florida 33181, USA

Tel.: +1 (305) 9194104, Email: jeremy.kiszka@ gmail.com 
Abstract: Sharks are a major component of the top predator guild in oceanic ecosystems, but their trophic relationships remain poorly understood. We examined chemical tracers of diet and habitat $\left(\delta^{15} \mathrm{~N}\right.$ and $\delta^{13} \mathrm{C}$, respectively) and total mercury $(\mathrm{Hg})$ concentrations in muscle tissue of seven pelagic sharks: blue shark (Prionace glauca), short-fin mako shark (Isurus oxyrinchus), oceanic whitetip shark (Carcharhinus longimanus), scalloped hammerhead shark (Sphyrna lewini), pelagic thresher shark (Alopias pelagicus), crocodile shark (Pseudocarcharias kamoharai) and silky shark (Carcharhinus falciformis), from the data poor south-western tropical Indian Ocean. Minimal interspecific variation in mean $\delta^{15} \mathrm{~N}$ values and a large degree of isotopic niche overlap - driven by high intraspecific variation in $\delta^{15} \mathrm{~N}$ values - was observed among pelagic sharks. Similarly, $\delta^{13} \mathrm{C}$ values of sharks overlapped considerably for all species with the exception of $P$. glauca, which had more ${ }^{13} \mathrm{C}$-depleted values indicating possibly longer residence times in purely pelagic waters. Geographic variation in $\delta^{13} \mathrm{C}, \delta^{15} \mathrm{~N}$ and $\mathrm{Hg}$ were observed for $P$. glauca and I. oxyrinchus. Mean Hg levels were similar among species with the exception of $P$. kamoharai which had significantly higher $\mathrm{Hg}$ concentrations likely related to mesopelagic feeding. $\mathrm{Hg}$ concentrations increased with body size in I. oxyrinchus, P. glauca and C. longimanus. Values of $\delta^{15} \mathrm{~N}$ and $\delta^{13} \mathrm{C}$ varied with size only in $P$. glauca, suggesting ontogenetic shifts in diets or habitats. Together, isotopic data indicate that - with few exceptions - variance within species in trophic interactions or foraging habitats is greater than differentiation among pelagic sharks in the south-western Indian Ocean. Therefore, it is possible that this group exhibits some level of trophic redundancy, but further studies of diets and fine-scale habitat use are needed to fully test this hypothesis.

Keywords: elasmobranchs; Indian Ocean; $\delta^{15} \mathrm{~N} ; \delta^{13} \mathrm{C}$; trace elements; intra-species variations. 


\section{Introduction}

Sharks are a major component of the top predator guild in open-ocean ecosystems along with tunas, billfish, and cetaceans. These "pelagic sharks" occur from cold temperate to tropical waters, from the surface to 1,000 $\mathrm{m}$ depth or more (Compagno 2008) and include some of the most wide-ranging marine predator species (Pikitch et al. 2008). Their extensive movements and ocean-basin scale migrations are most likely related to oligotrophy and the patchy nature of food resources in open-ocean ecosystems as well as directed movements for social and reproductive purposes. Many pelagic sharks use coastal/continental shelf waters in addition to open oceanic waters throughout ontogeny although certain biological functions, for example, gestation may be restricted to the open ocean (Compagno 1984, Bonfil 2008, Nakano and Stevens 2008). Even though pelagic sharks commonly occur in an environment far from human populations, they commonly overlap and interact with offshore fisheries. Currently, three-quarters of pelagic elasmobranchs are classified as Threatened or near Threatened (IUCN Red List Status), and 11 species are globally threatened with a high risk of extinction (Dulvy et al. 2008). Despite clear evidence for shark population declines, including oceanic ecosystems (Baum et al. 2003, Myers and Worm 2003, Estes et al. 2007, Heithaus et al. 2008), relatively little is known on the feeding ecology of many species and the ecological importance of this guild is poorly understood (Ferreti et al. 2010, Heithaus et al. 2010, Kitchell et al. 2002).

Sharks can play important roles in marine ecosystems through diverse mechanisms, but their relative importance may vary significantly among ecosystems, species and contexts (Heithaus et al. 2008, 2010). While the decline of large predatory sharks in some coastal ecosystems may 
initiate trophic cascades and affect overall community structure (see Heithaus et al. 2008, Ferretti et al. 2010 for reviews), it is still unclear whether the removal of pelagic sharks affects community structure in open-ocean ecosystems (Stillwell and Kohler 1982, Ward and Myers 2005). Evidence from ecosystem models from the central Pacific Ocean suggest pelagic shark declines may be mitigated by compensatory increases in populations of large teleosts (Kitchell et al. 2002). However, these models generally categorize pelagic sharks into a single homogenous trophic group when in fact there may be interspecific variation in habitat use and trophic interactions resulting in greater trophic complexity and less trophic redundancy than assumed for pelagic ecosystems. More ecological data on the relative trophic position and trophic interactions of oceanic sharks is required to test such model assumptions. If species are functionally redundant (i.e. they occupy similar trophic niches, hence consume the same prey base and perform the same functional role; Walker 1992), the loss of one or several may not result in large scale community rearrangements because of compensation by other species (e.g. Kitchell et al. 2002), but rather density compensation effects among the remaining species (Walker 1992). Recent studies suggest that sympatric shark species show considerable variation in trophic interactions (Hussey et al. 2011, Kinney et al. 2011, Speed et al. 2011). However, patterns of trophic redundancy within a given community are likely to be biologically and environmentally context-dependent (e.g. ocean productivity, intra-guild species richness), and are expected to vary accordingly.

In the tropical Indian Ocean (between $10^{\circ} \mathrm{N}$ and $10^{\circ} \mathrm{S}$ ), the most commonly caught pelagic sharks are blue (Prionace glauca), silky (Carcharhinus falciformis), pelagic thresher (Alopias pelagicus) and short-fin mako sharks (Isurus oxyrinchus). Between $10^{\circ} \mathrm{S}$ and $25^{\circ} \mathrm{S}$, sharks are less abundant and the community is dominated by P. glauca and I. oxyrinchus (Huang and Liu 2010). Despite 
evidence for high bycatch levels of pelagic sharks in the Indian Ocean (Romanov 2002, Huang and Liu 2010), there is a paucity of reliable data to facilitate assessing historical changes in shark catch rate trends (Smale 2008). Similarly, knowledge on the trophic ecology of pelagic sharks is limited in the Indian Ocean (and globally), particularly at the community level (Rabehagasoa et al. 2012).

The use of naturally occurring carbon and nitrogen stable isotopes provide chemical tracers to examine the ecology of organisms in a given ecosystem. Carbon and nitrogen stable isotopic ratios $\left(\delta^{13} \mathrm{C}\right.$ and $\left.\delta^{15} \mathrm{~N}\right)$ can depict the food webs in which consumers are foraging and their relative trophic position, respectively (Hobson 1999). Stable isotope analyses may provide complementary or, in some cases, an alternative method to traditional diet (e.g. based on analyses of stomach contents) and costly habitat and movement methodologies (e.g. telemetry). They have already been successfully used to understand elasmobranch ecology, including community trophic interactions and ontogenetic variation in trophic position and foraging habitats (Hussey et al. 2011, Kinney et al. 2011, Vaudo and Heithaus 2011).

Mercury ( $\mathrm{Hg}$ ) is a non-essential metal that is released from natural (e.g. volcanism) and anthropogenic sources (e.g. discharge by hydroelectric industries, mining), reaching the open ocean through runoff, riverine input and atmospheric deposition (Fitzgerald et al. 2007). Mercury provides an indicator of foraging habitats and trophic position of large marine predators because body burden concentrations are highly correlated to size/age, environmental parameters and geographic location (Rivers et al. 1972, Power et al. 2002, Colaço et al. 2006, Cai et al. 2007). Total $\mathrm{Hg}$ levels in pelagic fishes increase with median depth of occurrence in the water column and mesopelagic habitats are probably major entry points of mercury into marine food webs as a 
result of increased methylation at these depths (Monteiro et al. 1996, Choy et al. 2009, Chouvelon et al. 2012).

The aim of this work was to investigate the trophic interactions and potential overlap in foraging habitats of pelagic sharks from the south-western Indian Ocean using three complementary chemical tracers: $\delta^{15} \mathrm{~N}$ and $\delta^{13} \mathrm{C}$ and $\mathrm{Hg}$. Because tropical oceanic ecosystems are characterized by low productivity, we hypothesized that trophic plasticity would drive isotopic niche overlap among pelagic shark species, similarly to tropical seabirds and epipelagic tunas from the same region (Catry et al. 2008, Cherel et al. 2008, Kojadinovic et al. 2008). As a consequence of diet overlap, we hypothesized that $\mathrm{Hg}$ levels would be comparable among species reflecting a similar rate of $\mathrm{Hg}$ bioaccumulation. In addition, we also hypothesized that that size and $\delta^{15} \mathrm{~N}$ values would be positively correlated with $\mathrm{Hg}$ concentrations due to its bioaccumulation with age and its bioamplification within marine food webs.

\section{Materials and methods}

\subsection{Sampling}

Shark muscle samples were collected in the south-western Indian Ocean, from southern Madagascar to the Mascarene Islands (Fig. 1). Sharks were sampled during scientific longline fishing cruises or by observers on commercial longline fishing vessels from January 2009 to November 2010. The ecological characteristics of the pelagic shark species sampled are summarized in Table 1. For each individual shark caught, white muscle tissue was sampled from the base of the dorsal fin and immediately stored frozen. Once at the laboratory, the samples were 
freeze-dried, ground into a homogenous powder using a porcelain mortar and pestle, and then analyzed for stable isotopes $\left(\delta^{15} \mathrm{~N}\right.$ and $\left.\delta^{13} \mathrm{C}\right)$ and total $\mathrm{Hg}$. A total of 92 samples from 7 species were analyzed, including 31 Prionace glauca, 29 Isurus oxyrinchus, 13 Carcharhinus longimanus, 6 Sphyrna lewini, 5 Alopias pelagicus, 5 Pseudocarcharias kamoharai and 3 Carcharhinus falciformis (Table 2).

\subsection{Stable isotope analyses}

Because lipids are highly depleted in ${ }^{13} \mathrm{C}$ relative to other tissue components (De Niro and Epstein, 1977) and urea and trimethylamine oxide (TMAO) present in shark muscle tissue can alter $\delta^{15} \mathrm{~N}$ values, samples were lipid and urea/TMAO-extracted by two successive extractions prior to stable isotope analysis $(1 \mathrm{~h}$ shaking in $4 \mathrm{ml}$ cyclohexane at room temperature and subsequent centrifugation). This standardized data among individuals and across species within the food web (Hussey et al. 2012a, 2012b). After drying, lipid-free sub-samples (0.35 to $0.45 \mathrm{mg}$ $\pm 0.01 \mathrm{mg}$ ) were weighed in tin cups for stable isotope analysis. Stable isotope measurements were performed with a continuous-flow isotope-ratio mass spectrometer (Delta V Advantage, Thermo Scientific, Germany) coupled to an elemental analyzer (Flash EA1112 Thermo Scientific, Italy). Reference gas was calibrated against International Reference Materials (IAEAN1, IAEA-N2 and IAEA-N3 for nitrogen; NBS-21, USGS-24 and IAEA-C6 for carbon). Results are expressed in the $\delta$ notation relative to PeeDee Belemnite and atmospheric $\mathrm{N}_{2}$ for $\delta^{13} \mathrm{C}$ and $\delta^{15} \mathrm{~N}$, respectively, according to the equation:

$$
\delta X=\left[\left(R_{\text {sample }} / R_{\text {standard }}\right)-1\right] \times 10^{3}
$$


Where $X$ is ${ }^{13} \mathrm{C}$ or ${ }^{15} \mathrm{~N}$ and $R$ is the isotope ratio ${ }^{13} \mathrm{C} /{ }^{12} \mathrm{C}$ or ${ }^{15} \mathrm{~N} /{ }^{14} \mathrm{~N}$, respectively. Replicate measurements of a laboratory standard (acetanilide) indicated that analytical errors were $<0.1 \%$ for $\delta^{13} \mathrm{C}$ and $\delta^{15} \mathrm{~N}$. Percent $\mathrm{C}$ and $\mathrm{N}$ elemental composition of tissues were obtained using the elemental analyzer and the calculated C:N ratios were always below 3.5, indicating good lipid removal efficiency (Table 2).

\subsection{Hg analyses}

Total Hg measurements were performed using a solid sample atomic absorption spectrometer AMA-254 (Advanced Mercury Analyser-254 from Altec ${ }^{\circledR}$ ). At least two aliquots of 5 to $15 \mathrm{mg}$ of homogenized dry muscle tissue subsamples for each individual were analyzed. The analytical quality (i.e. accuracy and reproducibility) of the $\mathrm{Hg}$ measurements by the AMA-254 was assessed by the analyses of blanks and TORT-2 Certified Reference Material (Lobster Hepatopancreas Reference Material from the National Research Council of Canada) at the beginning and at the end of the analytical cycle, and by running it every 10 samples. Results of quality controls showed a satisfactory precision with a relative standard deviation of $6.0 \%$. The accuracy was $93 \%$ of the assigned concentration $(\mathrm{n}=14)$. The detection limit was $0.005 \mu \mathrm{g} \mathrm{g}^{-1}$ dry weight (dwt). All $\mathrm{Hg}$ concentrations in tissues reported below are expressed in $\mu \mathrm{g} \mathrm{g}^{-1} \mathrm{dwt}$.

\subsection{Trophic position $\left(T P_{15 N}\right)$ calculation}

Trophic position (TP) was calculated using a scaled $\Delta{ }^{15} \mathrm{~N}$ framework approach based on a dietary $\delta^{15} \mathrm{~N}$ value-dependent $\Delta^{15} \mathrm{~N}$ model (Hussey et al. 2014a and 2014b). In brief, with knowledge of the $\delta^{15} \mathrm{~N}$ value of a known baseline consumer $\left(\delta^{15} \mathrm{~N}_{\text {base }}\right)$, the $\delta^{15} \mathrm{~N}$ value of the consumer of interest $\left(\delta^{15} \mathrm{~N}_{\text {TP }}\right)$, the dietary $\delta^{15} \mathrm{~N}$ value at which ${ }^{15} \mathrm{~N}$ incorporation and ${ }^{15} \mathrm{~N}$ elimination are equal 
$\left(\delta^{15} \mathrm{~N}_{\text {lim }}\right)$ and the rate at which the ratio between ${ }^{15} \mathrm{~N}$ incorporation and ${ }^{15} \mathrm{~N}$ elimination changes relative to dietary $\delta^{15} \mathrm{~N}$ averaged across the food-web $(k)$, TP is calculated as follows:

$$
T P=\frac{\log \left({ }^{15} N_{\text {lim }}{ }^{15} N_{\text {base }}\right) \log \left({ }^{15} N_{\text {lim }}{ }^{15} N_{\text {TP }}\right)}{k}+T P_{\text {base }}
$$

Mobula japonica, a zooplanktivore (Last and Stevens 2009), was used as the baseline consumer $(\mathrm{TP}=3)$. Stable isotope values in white muscle samples from four individuals caught in offshore waters off southern Madagascar, during the sampling period, were (mean $\delta^{15} \mathrm{~N} \pm \mathrm{SD}$ ) $9.7 \pm 0.1$, similar to those reported for Mobula spp. off the east coast of South Africa (9.9 \pm 0.5 ; Hussey et al. 2011). A value of $\mathrm{k}=0.14$ and $\delta^{15} \mathrm{~N}_{\mathrm{lim}}=21.9$ were used following the meta-analysis of experimental isotopic studies conducted by Hussey et al. (2014a and 2014b).

\subsection{Data analysis}

We used Shapiro-Wilk tests to assess the assumptions of parametric tests. Hg data were logtransformed to reduce skewness and fit parametric requirements. ANOVA were used to test the influence of size (fork length), latitude, longitude, sex and species on $\delta^{13} \mathrm{C}$ and $\delta^{15} \mathrm{~N}$ values and on log-transformed Hg concentrations. Post-hoc Tukey HSD (Honesty Significance Difference) tests were used to investigate paired differences for significant factors. To investigate isotopic niche space and isotopic niche overlap among species we employed a Bayesian approach based on multivariate ellipse metrics (SIBER - Stable Isotope Bayesian Ellipses within the R-package siar; Jackson et al. 2011). Standard ellipses are bivariate data calculated from the variance and covariance of the data matrix ( $\mathrm{x}, \mathrm{y}$ parameters) and represent the core isotopic niche for a species. This analysis generates standard ellipse areas corrected for small sample sizes (SEAc) which can 
be compared among species to determine differences in core isotopic niche space and niche overlap (Jackson et al. 2011). The calculation of standard ellipses (SEAc) was undertaken for $\delta^{15} \mathrm{~N}$ vs. $\delta^{13} \mathrm{C}$ data, but also for combinations of $\delta^{13} \mathrm{C}$ vs. $\mathrm{Hg}$ and $\delta^{15} \mathrm{~N}$ vs. $\mathrm{Hg}$ data to provide complementary tracer information. The degree of niche overlap among species for each combination of the above data parameters, i.e. the overlap in species' standard ellipse (SEAc) areas was then calculated using the OVERLAP command. Pearson's correlations were used to examine $\delta^{13} \mathrm{C}$ and $\delta^{15} \mathrm{~N}$ values vs. $\log \mathrm{Hg}$ concentrations, as well as the relationship between $\delta^{13} \mathrm{C}$ and $\delta^{15} \mathrm{~N}$ values. Statistical analyses were performed using R 2.12.0 (R Development Core Team, 2010).

\section{Results}

\subsection{Inter-species variations}

Values of $\delta^{15} \mathrm{~N}$ and $\delta^{13} \mathrm{C}$ and $\mathrm{Hg}$ concentrations varied significantly among species (one-way ANOVA, $\mathrm{F}_{6,85}=5.94 ; \mathrm{p}<0.001 ; \mathrm{F}_{6,85}=11.23, \mathrm{p}<0.001 ; \mathrm{F}_{6,85}=5.41, \mathrm{p}<0.001$, respectively; Figs. 2 and 3, Table 2). There were, however, relatively few significant pairwise comparisons (Table 3). For $\delta^{15} \mathrm{~N}$, I. oxyrinchus had significantly higher values than $C$. falciformis $(\mathrm{p}<0.01$ ), C. longimanus $(\mathrm{p}<0.01)$ and $P$. glauca $(\mathrm{p}<0.001)$. For $\delta^{13} \mathrm{C}$, the only significant pairwise comparison was between $P$. glauca and all species except $C$. falciformis. Concerning $\log \mathrm{Hg}$ concentrations, pairwise comparisons between P. kamoharai and the other species were all significant (Table 3). Moreover, $\log \mathrm{Hg}$ concentrations were significantly higher in I. oxyrinchus than in C. falciformis ( $<<0.01$, Table 3). 
Standard $\delta^{15} \mathrm{~N}-\delta^{13} \mathrm{C}$ ellipses (SEAc) identified considerable niche overlap among species, with few exceptions (Fig. 4, Table 4). For P. glauca, no ellipse overlap occurred with C. longimanus, P. kamoharai and S. lewini and there was very limited overlap with A. pelagicus (Fig. 4). S. lewini showed a high degree of niche overlap with $C$. longimanus and P. kamoharai. Niche space represented by ellipse size was the largest for S. lewini (2.7), similar for I. oxyrinchus, P. glauca, C. longimanus and A. pelagicus (1.0, 1.2, 1.5 and 1.2, respectively) and smallest for $P$. kamoharai (0.3, Fig. 4; Table 4). When considering the $\delta^{13} \mathrm{C}$ vs. $\mathrm{Hg}$ and $\delta^{15} \mathrm{~N}$ vs. $\mathrm{Hg}$ standard ellipses (SEAc; Figs. 5 and 6), P. kamoharai showed significant niche space separation from all other species with the exception of $C$. longimanus (Tables 6 and 7). Most species showed considerable niche overlap in terms of $\mathrm{Hg}$ vs. $\delta^{13} \mathrm{C}$ and $\mathrm{Hg}$ vs. $\delta^{15} \mathrm{~N}$ space (Figs. 5 and 6; Tables 5 and 6). For both $\delta^{13} \mathrm{C}$ vs. $\mathrm{Hg}$ and $\delta^{15} \mathrm{~N}$ vs. $\mathrm{Hg}$, C. longimanus had the largest ellipse area (12.3 and 27.4, respectively), while $P$. glauca had the smallest (2.3 and 5.3, respectively; Figs. 5 and 6; Table 5 and 6).

Estimated TPs of all pelagic shark species based on $\delta^{15} \mathrm{~N}$ values $\left(\mathrm{TP}_{15 \mathrm{~N}}\right)$ spanned 1.8 trophic positions ranging from TP 3.5 for a $99 \mathrm{~cm}$ FL C. longimanus to TP 5.3 for a $173 \mathrm{~cm}$ FL $I$. oxyrinchus (Table 2). Overall I. oxyrinchus fed at the highest mean TP (4.7 SD \pm 0.3$)$ and $C$. falciformis at the lowest mean TP $(3.8 \pm 0.1)$, with all other species feeding at a similar level (mean $\mathrm{TP} \sim 4.3$ ). High intraspecific variation in $\mathrm{TP}_{15 \mathrm{~N}}$ was observed with most species estimated to be feeding over one trophic level. 


\subsection{Geographic, size and sex-related variation}

Values of $\delta^{13} \mathrm{C}, \delta^{15} \mathrm{~N}$ and $\mathrm{Hg}$, increased with increasing longitude for I. oxyrinchus $\left(\mathrm{F}_{1,90}=6.41\right.$, $\mathrm{p}<0.05)$. For $P$. glauca, there were significant increasing $\log \mathrm{Hg}$ concentrations when latitude increased $\left(\mathrm{F}_{1,90}=13.93, \mathrm{p}<0.001\right)$ and $\delta^{13} \mathrm{C}$ values decreased with increasing latitude $\left(\mathrm{F}_{1,90}=\right.$ $10.31, \mathrm{p}<0.01$ ). A significant positive effect of longitude on $\delta^{15} \mathrm{~N}$ values was also detected in $P$. glauca $\left(\mathrm{F}_{1,90}=8.12, \mathrm{p}<0.01\right)$. When considering all species combined, there was a significant positive effect of size on log $\mathrm{Hg}$ concentrations (one-way ANOVA, $\mathrm{F}_{1,90}=7.03, \mathrm{p}<0.01$ ) and on $\delta^{13} \mathrm{C}$ values $\left(\mathrm{F}_{1,90}=6.48, \mathrm{p}<0.05\right)$, but not for $\delta^{15} \mathrm{~N}\left(\mathrm{~F}_{1,90}=3.70, \mathrm{p}>0.05\right)$.

At the species level, the effect of size on $\log \mathrm{Hg}$ concentrations was significant for I. oxyrinchus $\left(\mathrm{F}_{1,27}=16.1, \mathrm{p}<0.001\right.$, Fig. 7a $)$, P. glauca $\left(\mathrm{F}_{1,29}=23.7, \mathrm{p}<0.001\right.$, Fig. $\left.7 \mathrm{~b}\right)$ and C. longimanus $\left(\mathrm{F}_{1,11}=15.9, \mathrm{p}<0.01\right.$, Fig. $\left.7 \mathrm{c}\right)$. There was a positive relationship between size and both $\delta^{15} \mathrm{~N}$ and $\delta^{13} \mathrm{C}$ in $P$. glauca $\left(\mathrm{F}_{1,11}=11.3, \mathrm{p}<0.01\right.$ and $\mathrm{F}_{1,11}=25.1, \mathrm{p}<0.001$, respectively, Fig. $\left.7 \mathrm{~b}\right)$, but not for any other species examined. There was no detectable variation in $\delta^{15} \mathrm{~N}$ and $\delta^{13} \mathrm{C}$ values and $\mathrm{Hg}$ concentrations between sexes (one-way ANOVA for $\log \mathrm{Hg}, \delta^{13} \mathrm{C}$ and $\delta^{15} \mathrm{~N}$; all $\mathrm{p}>0.05$ ).

\subsection{Relationships between $\delta^{15} N$, $\delta^{13} C$ and $H g$ concentrations}

For all data combined, there was a significant correlation between $\log \mathrm{Hg}$ concentrations and $\delta^{15} \mathrm{~N}$ values (Pearson: $\left.r=0.38, \mathrm{df}=90, \mathrm{p}<0.001\right)$ but not for $\delta^{13} \mathrm{C}(r=0.12, \mathrm{df}=90, \mathrm{p}>0.05$, Table 7). At the species level, positive correlations between $\log \mathrm{Hg}$ and $\delta^{15} \mathrm{~N}$, and $\log \mathrm{Hg}$ and $\delta^{13} \mathrm{C}$ were only significant for $P$. glauca $(r=0.64, \mathrm{df}=29, \mathrm{p}<0.001$ and $r=0.71, \mathrm{p}<0.001$, respectively). There was a significant positive correlation between $\delta^{13} \mathrm{C}$ and $\delta^{15} \mathrm{~N}$ for $C$. 
falciformis $(r=-0.99, \mathrm{p}<0.05), P$. glauca $(r=0.71, \mathrm{p}<0.001)$ and $I$. oxyrinchus $(r=0.67, \mathrm{df}=$ $27, \mathrm{p}<0.001 ;$ Table 7).

\section{Discussion}

Understanding interspecific variation in trophic interactions and foraging base of pelagic sharks based on size, sex and geographic location is important for elucidating the role of this predator guild in pelagic ecosystems. Traditionally considered to be a trophically redundant group, our data suggest the potential for high levels of intraspecific variation in trophic interactions or foraging locations that obscures differences among species within the guild as a whole. These data identify species trophic plasticity as would be predicted in the oligotrophic pelagic realm of the western Indian Ocean. In addition, this study extends our understanding of ontogenetic shifts (studied for $P$. glauca in the Mozambique Channel and off eastern Madagascar; Rabehagasoa et al. 2012), and provides the first $\mathrm{Hg}$ concentrations for this data poor region. However, considering the limited sample size for a number of species, our results should be interpreted with caution.

\subsection{Patterns of isotopic niche partitioning}

Intraspecific variation in estimated trophic positions was considerable, with most species feeding over more than a single trophic level. However, as hypothesized and assumed by models of pelagic ecosystems, interspecific variation in average trophic positions was limited among species in our study area. The notable exception to this pattern was I. oxyrinchus, which exhibited significantly higher $\delta^{15} \mathrm{~N}$ values, likely because of their propensity to forage on large predatory 
fish, including small elasmobranchs and marine mammals (Cliff et al. 1990). Our mean species TP results provided similar estimates to those based on stomach contents by Cortes (1999), but overall the TP range was slightly higher, a result of using the more accurate scaled $\Delta^{15} \mathrm{~N}$ framework (Hussey et al. 2014a, 2014b). Nonetheless, our results suggest that pelagic sharks from the study region generally occupy similar trophic positions, and that intraspecific variation is much greater than interspecific variation. Surprisingly, calculated $\mathrm{TP}_{15 \mathrm{~N}}$ for $P$. kamoharai was relatively high (mean value $=4.5)$ given the small body size of this species $(<100 \mathrm{~cm})$. Stomach contents of $P$. kamoharai suggest a diet of small mesopelagic teleosts, cephalopods and shrimps (Compagno 1984). The high $\delta^{15} \mathrm{~N}$ values and estimated trophic position for this species may be a result of a higher nitrogen baseline value in the deep-sea food web where this species forages. This would bias the comparison of $\delta^{15} \mathrm{~N}$ values and estimated TP among species, given the other species feed predominantly in the epipelagic zone. Alternatively, this could suggest the existence of a longer food chain at smaller body sizes in these deep-water environments than previously anticipated. Further analyses are required in the future to test these hypotheses.

Most species had similar $\delta^{13} \mathrm{C}$ values suggesting a high degree of overlap in habitat use. The principal exception was $P$. glauca which was more depleted in ${ }^{13} \mathrm{C}$ compared to the other species. There is a limited diversity of carbon sources in open-ocean systems, particularly in oligotrophic environments, and detrital carbon sources are likely to be the most available. $\delta^{13} \mathrm{C}$ values commonly decrease from productive continental shelf waters to pelagic systems with coastal species having amore enriched ${ }^{13} \mathrm{C}$ values (Cherel et al. 2008, Kiszka et al. 2011, Chouvelon et al. 2012). The $\delta^{13} \mathrm{C}$ values of most shark species were intermediate to these environments, indicating the use of both pelagic and coastal waters (Hussey et al. 2011). Lower $\delta^{13} \mathrm{C}$ values of $P$. glauca, indicate this species spends longer periods of time in pelagic vs. coastal waters and/or forages in 
more ${ }^{13} \mathrm{C}$-depleted deeper waters. This is supported by satellite tracking data of $P$. glauca in the North Atlantic (Campana et al. 2011).

Overall, our results confirm high core isotopic niche overlap among pelagic sharks in the western Indian Ocean. A similar pattern was previously reported for other pelagic sharks in the temperate waters of the North Atlantic, specifically P. glauca and I. oxyrinchus (Estrada et al. 2003) and other oceanic top predator guilds, including tunas and tropical seabirds in the western Indian Ocean (Catry et al. 2008, Cherel et al. 2008, Kojadinovic et al. 2008). This degree of overlap in core isotopic niches of pelagic sharks and other pelagic predator guilds is likely driven largely by the homogeneity of carbon sources in oligotrophic open-ocean ecosystems, characterized by low productivity and little seasonality (Cherel et al. 2008).

\subsection{Hg as a complementary dietary tracer}

$\mathrm{Hg}$ levels which provide insights into the trophic position of organisms (e.g. McMeans et al. 2010), were relatively similar among species. A positive relationship between $\mathrm{Hg}$ concentrations and $\delta^{15} \mathrm{~N}$ has been previously documented for many marine taxa, including pelagic sharks from other regions in the Atlantic and Pacific Oceans (e.g. Branco et al. 2004, Maz-Courrau et al. 2012). Our results for P. glauca, I. oxyrinchus and C. longimanus (species with satisfactory sample size) are consistent with this pattern. Overall, $\mathrm{Hg}$ concentrations in muscle tissues were very high in pelagic sharks sampled in the south-western Indian Ocean (mean $=6.34 \mu \mathrm{g} \cdot \mathrm{g}^{-1} \mathrm{dw}$ ), compared to other pelagic fish from the same region, including Xiphias gladius $(\mathrm{mean}=3.97$ $\left.\mu \mathrm{g} \cdot \mathrm{g}^{-1} \mathrm{dw}\right)$, Thunnus albacares $\left(1.15 \mu \mathrm{g} \cdot \mathrm{g}^{-1} \mathrm{dw}\right)$, Thunnus obesus $\left(0.67 \mu \mathrm{g} \cdot \mathrm{g}^{-1} \mathrm{dw}\right)$ and Coryphaena hippurus $\left(0.21 \mu \mathrm{g} \cdot \mathrm{g}^{-1} \mathrm{dw}\right)$ (Kojadinovic et al. 2006). The total $\mathrm{Hg}$ levels in blue shark muscle samples of a similar size were also much higher in the south-western Indian Ocean 
compared to those reported off Baja California (central Pacific Ocean) $\left(1.96 \pm 1.48 \mu \mathrm{g} \cdot \mathrm{g}^{-1} \mathrm{dw} v s\right.$. $5.3 \pm 2.17$ in our study, Maz-Courrau et al. 2012). These concentrations highlight not only the high trophic position of these species but the potential risks of shark meat consumption for human health that need to be further investigated.

The high $\mathrm{Hg}$ concentrations observed in $P$. kamoharai $\left(\right.$ mean $=17.25 \mu \mathrm{g}^{-g^{-1}} \mathrm{dw}$ ) were unexpected, since this species appears to feed at a similar trophic position to most other pelagic species, based on $\delta^{15} \mathrm{~N}$ despite being much smaller in size $(<100 \mathrm{~cm})$. In addition the mean $\delta^{13} \mathrm{C}$ value of $P$. kamoharai was also similar to other species indicating it is unlikely feeding from a different carbon pool. P. kamoharai is a poorly known shark species that occurs in oceanic circumtropical waters around the world (Compagno 1984). The morphology of the P. kamoharai, particularly large eye size, suggests a deep-water habitat for this species, but with movements toward the surface at night (Compagno 1984). Methyl-Hg is produced by the methylation of inorganic $\mathrm{Hg}$ in deep oceanic waters (Blum et al. 2013), resulting in its enhanced bioaccumulation in mesopelagic organisms (Monteiro et al. 1996, Chouvelon et al. 2012). Therefore, top marine predators feeding on mesopelagic prey, such as seabirds and large predatory fishes, exhibit significantly higher concentrations than epipelagic predators (Thompson et al. 1998, Kojadinovic et al. 2006, Choy et al. 2009). In this respect, $\mathrm{Hg}$ can be considered as an indicator of the feeding depth (Carravieri et al. 2013). Higher Hg concentrations in P. kamoharai, are most likely due to its occupying a significantly deeper feeding habitat than the other, more surface-oriented, pelagic species sampled. 


\subsection{Spatial and ontogenetic variation}

Spatial variation in $\delta^{13} \mathrm{C}$ and $\delta^{15} \mathrm{~N}$ values and $\mathrm{Hg}$ concentrations of individual sharks sampled were not consistent, especially for P. glauca and I. oxyrinchus. Drawing conclusions on these inconsistent patterns is difficult because there are currently no complementary independent datasets from this region to provide insights into isoscapes or geographical patterns of $\mathrm{Hg}$ concentrations. Information on size and sex-based differences in trophic interactions of marine top predators, including sharks, is critical to better understand ecosystem function and to assess the ecological role of these organisms. Ontogenetic shifts in diet are common in elasmobranchs, for large predatory species such as tiger (Galeocerdo cuvier, Lowe et al. 1996) and great white sharks (Carcharodon carcharias, Estrada et al. 2006) to zooplanktivorous whale sharks (Rhincodon typus, Borrell et al. 2011). Ontogenetic variation in the foraging ecology and habitat use of most pelagic sharks investigated in this study are poorly known, except for P. glauca, including in the western Indian Ocean. Previous studies suggest a significant increase in $\delta^{13} \mathrm{C}$ and $\delta^{15} \mathrm{~N}$ values with body length in $P$. glauca in the surrounding oceanic waters of Madagascar, but not in $C$. falciformis (Rabehagasoa et al. 2012). Our data suggest an identical pattern for $P$. glauca (not tested for $C$. falciformis due to small sample size), which is also consistent with a significant dietary shift with increasing size based on stomach content analyses in Baja California (Markaida and Sosa-Nishizaki 2010).

\section{Conclusion}

In this study, we found a high degree of isotopic niche overlap among pelagic sharks in the oligotrophic waters of the south-western Indian Ocean that is consistent with previous studies on other epipelagic marine top predators. Nevertheless, our data also found large intra-species 
variation in $\delta^{15} \mathrm{~N}$ values identifying dietary and foraging habitat plasticity that masks variation among species. This large intra-species variation in $\delta^{15} \mathrm{~N}$ values would suggest pelagic species are either opportunistic feeders or have evolved variable and complex feeding behaviors, potentially related to variable regional prey bases and the migratory nature of these animals. Nevertheless a high degree of dietary plasticity would be expected in oligotrophic waters and intra-species variation should be investigated further in other pelagic guilds. Although, at the species level, significant core isotopic and $\mathrm{Hg}$ niche overlap among species is consistent with the hypothesis of trophic redundancy, these results must be viewed with caution due to limited differentiation in carbon pools in this ecosystem coupled with high intra-species variation.

\section{Acknowledgements}

Our particular thanks are addressed to sample collectors during longline fishing cruises and IFREMER (IOSSS-Espadon project) for providing shark samples. Special thanks are addressed to J. Bourjea (IFREMER, La Réunion) for coordinating the collation of shark samples. We are also very grateful to G. Guillou and P. Richard (University of La Rochelle, lab. LIENSs) for running the mass spectrometer analyses. Sample analysis was supported by the CPER (Contrat de Projet Etat-Région). 


\section{References}

Baum, J.K., Myers, R.A., Kehler, D.G., Worm, B., Harley, S.J., Doherty, P.A. 2003. Collapse and conservation of shark populations in the Northwest Atlantic. Science 299, 389-392.

Blum, J.D., Popp, B.N., Drazen, J.C., Anela Choy, C., Johnson, M.W. 2013 Methylmercury production below the mixed layer in the North Pacific Ocean. Nature Geoscience 6, 879884.

Bonfil, R. 2008. The biology and ecology of the silky shark, Carcharhinus falciformis. In: Sharks of the Open Ocean (eds. M.D. Camhi, E.K. Pikitch, E.A. Babcock), Blackwell Publishing, Oxford, UK, pp. 114-127.

Bonfil, R., Clarke, S., Nakano, H. 2008. The biology and ecology of the oceanic whitetip shark, Carcharhinus longimanus. In: Sharks of the Open Ocean (eds. M.D. Camhi, E.K. Pikitch, E.A. Babcock), Blackwell Publishing, Oxford, UK, pp. 128-139.

Borrell, A., Aguilar, A., Gazo, M., Kumarran, R.P., Cardona, L. 2011. Stable isotope profiles in whale shark (Rhincodon typus) suggest segregation in the diet depending on sex and size. Environmental Biology of Fishes 92, 559-557.

Branco, V., Canario, J., Vale, C., Raimundo, J., Reis, C., 2004. Total and organic mercury concentrations in muscle tissues of the blue shark (Prionace glauca L. 1758) from the northeast Atlantic. Marine Pollution Bulletin 49, 854-874.

Cabrera-Chávez-Costa, A.A., Galván-Magaña, F., Escobar-Sánchez, O.E., 2010. Food habits of the silky shark Carcharhinus falciformis (Müller \& Henle, 1839) off the western coast of Baja California Sur, Mexico. Journal of Applied Ichtyology 26, 499-503.

Cai, Y., Rooker, J.R., Gill, G.A., Turner, J.P. 2007. Bioaccumulation of mercury in pelagic fishes from the northern Gulf of Mexico. Canadian Journal of Fisheries and Aquatic Sciences 64, 458-469. 
Carravieri, A., Bustamante, P., Churlaud, C., Cherel, Y. 2013. Penguins as bioindicators of mercury contamination in the Southern Ocean: birds from the Kerguelen Islands as a case study. Science of the Total Environment 454, 141-148.

Casey, J.G., Kohler, N.E., 1992. Tagging studies on the short-fin mako (Isurus oxyrinchus) in the western North Atlantic. Australian Journal of Marine and Freshwater Research 43, 45-60.

Catry, C., Ramos, J.A., Le Corre, M., Kojadinovic, J., Bustamante, P., 2008. The role of stable isotopes and mercury concentrations to describe seabird foraging ecology in tropical environments. Marine Biology 155, 637-647.

Cherel, Y., Le Corre, M., Jaquemet, S., Ménard, F., Richard, P., Weimerskirch, H., 2008. Resource partitioning within a tropical seabird community: new information from stable isotopes. Marine Ecology Progress Series 366, 281-291.

Chouvelon, T., Spitz, J., Caurant, F., Mèndez-Fernandez, P., Autier, J., Lassus-Débat, A., Chappuis, A., Bustamante, P., 2012. Enhanced bioaccumulation of mercury in deep-sea fauna from the Bay of Biscay (north-east Atlantic) in relation to trophic positions identified by analysis of carbon and nitrogen isotopes. Deep Sea Research Part I 65, 113-124.

Choy, C.A., Popp, B.N., Kaneko, J.J., Drazen, J.C., 2009. The influence of depth on mercury levels in pelagic fishes and their prey. Proceedings of the National Academy of Science USA 106, 13865-13869.

Cliff, G., Dudley, S.F.J., Davis, B., 1990. Sharks caught in the protective gill nets off Natal, South Africa. 3. The shortfin mako shark Isurus oxyrinchus (Rafinesque). South African Journal of Marine Science 9, 115-126.

Colaço, A., Bustamante, P., Fouquet, Y., Sarradin, P.M., Serrao-Santos, R. 2006. Bioaccumulation of $\mathrm{Hg}, \mathrm{Cu}$, and $\mathrm{Zn}$ in the Azores triple junction hydrothermal vent fields food web. Chemosphere 65, 2260-2267. 
Compagno, L.J.V. 1984. FAO species catalogue. Vol. 4. Sharks of the world. An annotated and illustrated catalogue of shark specimen known to date. Part 2. Carcharhiniformes. FAO Fish. Synop., (125) Vol.4, Pt.2: 251-655.

Compagno, L.J.V. 2008. Pelagic elasmobranch diversity. In: Sharks of the Open Ocean (eds. M.D. Camhi, E.K. Pikitch, E.A. Babcock), Blackwell Publishing, Oxford, UK, pp. 14-23. Cortés, E. 1999. Standardized diet compositions and trophic levels of sharks. ICES Journal of Marine Science 56, 107-117.

De Niro, M.J., Epstein, S. 1977. Mechanism of carbon fractionation associated with lipid synthesis. Science 197, 261-263.

Dray, S., Dufour, A.B. 2007. The ade4 package: implementing the duality diagram for ecologists. Journal of Statistical Software 22, 1-20.

Dulvy, N.K., Baum, J.K., Clarke, S., Compagno, L.J.V., Cortés, E., Domingo, A., Fordham, S., Fowler, S., Francis, M.P., Gibson, C., Martínez, J., Musick, J.A., Soldo, A., Stevens, J.D., Valenti, S. 2008. You can swim but you can't hide: the global status of and conservation of pelagic sharks and rays. Aquatic Conservation: Marine and Freshwater Ecosystems 18, 459-482.

Estrada, J.A., Rice, A.N., Lutcavage, M.E., Skomal, G.B. 2003. Predicting trophic position of sharks in the north-west Atlantic Ocean using stable isotope analysis. Journal of the Marine Biological Association of the United Kingdom 83, 1347-1350.

Estrada, J.A., Rice, A.N., Natanson, N.J., Skomal, G.B. 2006. Use of isotopic analysis from vertebrae in reconstructing ontogenetic feeding ecology in white sharks. Ecology 87, 829834.

Ferretti, F., Worm, B., Britten, G.L., Heithaus, M.R., Lotze, H.K. 2010. Patterns and ecosystem consequences of shark declines in the ocean. Ecology Letters 13, 1055-1071. 
Fitzgerald, W.F., Lamborg, C.H., Hammerschmidt, C.R. 2007. Marine biochemical cycling of mercury. Chemical Review 107, 641-662.

Gelsteichter, J., Walker, C.J. 2010. Pollutant exposure and effects on sharks and their relatives. In: Sharks and Their Relatives II: Biodiversity, Adaptative Physiology and Conservation (eds. J.C. Carrier, J.A. Musick and M.R. Heithaus). CRC Press, Boca Raton, FL (USA), pp. 491-537.

Gray, J.S. 2002. Biomagnification in marine systems: the perspective of an ecologist. Marine Pollution Bulletin 45, 46-52.

Heithaus, M.R., Frid, A., Vaudo, J.J., Worm, B., Wirsing, A.J. 2010. Unraveling the ecological importance of elasmobranchs. In: Sharks and Their Relatives II: Biodiversity, Adaptative Physiology and Conservation (eds. J.C. Carrier, J.A. Musick and M.R. Heithaus). CRC Press, Boca Raton, FL (USA), pp. 611-636.

Heithaus, M.R., Frid, A., Wirsing, A.J., Worm, B. 2008. Predicting ecological consequences of marine top predator declines. Trends in Ecology and Evolution 23, 202-210.

Hobson, K.A. 1999. Tracing origins and migration of wildlife using stable isotopes: a review. Oecologia 120, 314-326.

Hobson, K.A., Welch, H.E. 1992. Determination of trophic relationships within a high Arctic food web using $\delta^{13} \mathrm{C}$ and $\delta^{15} \mathrm{~N}$ analysis. Marine Ecology Progress Series 84, 9-18.

Huang, H.-W., Liu, K.-M. 2010. Bycatch and discards by Taiwanese large-scale tuna longline fleets in the Indian Ocean. Fisheries Research 106, 261-270.

Hussey, N.E., Brush, J., McCarthy, I.D., Fisk, A.T. 2010. $\delta^{15} \mathrm{~N}$ and $\delta^{13} \mathrm{C}$ diet-tissue discrimination factors of large sharks under semi-controlled conditions. Comparative Biochemistry and Physiology Part A: Molecular and Integrative Physiology 155, 445-453. 
Hussey, N.E., Dudley, S.F.J., McCarthy, I.D., Cliff, G., Fisk, A.T. 2011. Stable isotope profiles of large marine predators: viable indicators of trophic position, diet and movement in sharks? Canadian Journal of Fisheries and Aquatic Sciences 68, 2029-2045.

Hussey, N.E., MacNeil, M.A., Olin, J.A., McMeans, B.C., Kinney, M.J., Chapman, D.D., Fisk, A.T. 2012a. Stable isotopes and elasmobranchs: tissue types, methods, applications and assumptions. Journal of Fish Biology 80, 1449-1484.

Hussey, N.E., Olin, J.A., Kinney, M.J., McMeans, B.C., Fisk, A.T. 2012b. Lipid extraction effects on stable isotope values $\left(\delta^{13} \mathrm{C}\right.$ and $\left.\delta^{15} \mathrm{~N}\right)$ of elasmobranch muscle tissue. Journal of Experimental Marine Biology and Ecology 434-435: 7-15

Hussey, N.E., MacNeil, M.A., McMeans, B.C., Olin, J.A., Dudley, S.F.J., Cliff, G., Wintner, S.P., Fennessy, S.T., Fisk, A.T. 2014a. Rescaling the trophic structure of marine food webs. Ecology Letters 17, 239-250.

Hussey, N.E., MacNeil, M.A., McMeans, B.C., Olin, J.A., Dudley, S.F.J., Cliff, G., Wintner, S.P., Fennessy, S.T., Fisk, A.T. 2014b. Corrigendum to Hussey et al. (2014). Ecology Letters 17,768 .

Kimley, A.P. 1993. Highly directional swimming by scalloped hammerhead sharks, Sphyrna lewini, and subsurface irradiance, temperature, bathymetry and geomagnetic field. Marine Biology 117, 1-22.

Kinney, M.J., Hussey, N.E., Fisk, A.T., Tobin A.J., Simpfendorfer, C.A. 2011. Communal or competitive? Stable isotope analysis provides evidence of resource partitioning within a communal shark nursery. Marine Ecology Progress Series 439, 263-276.

Kiszka, J., Simon-Bouhet, B., Martinez, L., Richard, P., Pusineri, C., Ridoux, V. 2011. Ecological niche segregation within a community of sympatric dolphins around a tropical island. Marine Ecology Progress Series 433, 273-288. 
Kitchell, J.F., Essington, T.E., Boggs, C.H., Schindler, D.E., Walters, C.J. 2002. The role of sharks and longline fisheries in a pelagic ecosystem of the central Pacific. Ecosystems 5, 2002-2016.

Kojadinovic, J., Potier, M., Le Corre, M., Cosson, R.P., Bustamante, P. 2006. Mercury content in commercial pelagic fish and its risk assessment in the Western Indian Ocean. Science of the Total Environment 366, 688-700.

Kojadinovic, J., Ménard, F., Bustamante, P., Cosson, R.P., Le Corre, M. 2008. Trophic ecology of marine birds and pelagic fishes from Reunion Island as determined through stable isotope analysis. Marine Ecology Progress Series 361, 239-251.

Last, P.R., Stevens, J. D. 2009. Sharks and rays of Australia. Harvard University Press, London

Lowe, C., Wetherbee, B.M., Crow, G.L., Tester, A.L. 1996. Ontogenetic dietary shifts and feeding behavior of tiger sharks, Galeocerdo cuvier, in Hawaiian waters. Environmental Biology of Fishes 47, 203-211.

Markaida, U., Sosa-Nishizaki, O. 2010. Food and feeding habits of the blue shark Prionace glauca caught off Ensenada, Baja California, Mexico, with a review on its feeding. Journal of the Marine Biological Association of the United Kingdom 90, 977-994.

Maz-Courrau, A., López-Vera, C., Galván-Magaña, Escobar-Sánchez, O., Rosíles-Martínez, R., Sanjuán-Muñoz, A. 2012. Bioaccumulation and biomagnification of total mercury in four exploited shark species in the Baja California peninsula, Mexico. Bulletin of Environmental Contamination and Toxicology 88, 129-134.

McMeans, B.C., Svavarsson, J., Dennard, S., Fisk, A. 2010. Diet and resource use among Greenland sharks (Somniosus microcephalus) and teleosts sampled in Icelandic waters using $\delta^{13} \mathrm{C}, \delta^{15} \mathrm{~N}$, and mercury. Canadian Journal of Fisheries and Aquatic Sciences 67, 1428-1438. 
Ménard, F., Lorrain, A., Potier, M., Marsac, F. 2007. Isotopic evidence of distinct feeding ecologies and movement patterns in two migratory predators (yellowfin tuna and swordfish) of the western Indian Ocean. Marine Biology 153, 141-152.

Monteiro, L.R., Costa, V., Furness, R.W., Santos, R.S. 1996. Mercury concentrations in prey fish indicate enhanced bioaccumulation in mesopelagic environments. Marine Ecology Progress Series 141, 21-25.

Myers, R.A., Worm, B. 2003. Rapid worldwide depletion of predatory fish communities. Nature $423,280-283$.

Nakano, H., Stevens, J.D. 2008. The biology and ecology of the blue shark, Prionace glauca. In: Sharks of the Open Ocean (eds. M.D. Camhi, E.K. Pikitch, E.A. Babcock), Blackwell Publishing, Oxford, UK, pp. 140-151.

Pitkitch, E.K., Camhi, M.D., Babcock, E.A. 2008. Introduction to sharks of the open ocean. In: Sharks of the Open Ocean (eds. M.D. Camhi, E.K. Pikitch, E.A. Babcock), Blackwell Publishing, Oxford, UK, pp. 3-13.

Power, M., Klein, G.M., Guiguer, K.R.R.A., Kwan, M.K.H. 2002. Mercury accumulation in the fish community of a sub-Arctic lake in relation to trophic position and carbon sources. Journal of Applied Ecology 39, 819-830.

Rabehagasoa, N., Lorrain, A., Bach, P., Potier, M., Jaquemet, S., Richard, P., Ménard, F. 2012. Isotopic niches of the blue shark Prionace glauca and the silky shark Carcharhinus falciformis in the southwestern Indian Ocean. Endangered Species Research 17, 83-92.

Rivers, J.B., Pearson, J.E., Shultz, C.D. 1972. Total and organic mercury in marine fish. Bulletin of Environmental Contamination and Ecotoxicology 8, 257-266.

Romanov, E.V. 2002. Bycatch in the tuna purse-seine fisheries of the western Indian Ocean. Fishery Bulletin 100, 90-105. 
Smale, M.J. 2008. Pelagic shark fisheries in the Indian Ocean. In: Sharks of the Open Ocean (eds. M.D. Camhi, E.K. Pikitch, E.A. Babcock), Blackwell Publishing, Oxford, UK, pp. 247259.

Smith, S.E., Rasmussen, R.C., Ramon, D.A., Caillet, G.M. 2008. The biology and ecology of thresher sharks (Alopiidae). In: Sharks of the Open Ocean (eds. M.D. Camhi, E.K. Pikitch, E.A. Babcock), Blackwell Publishing, Oxford, UK, pp. 60-68

Speed, C.W., Meekan, M.G., Field, I.C., McMahon, C.R., Abrantes, K., Bradshaw, C.J.A. 2011. Trophic ecology of reef sharks determined using stable isotopes and telemetry. Coral Reefs $31,357-367$.

Stevens, J.D. 2008. The biology and ecology of the shortfin mako shark, Isurus oxyrinchus. In: Sharks of the Open Ocean (eds. M.D. Camhi, E.K. Pikitch, E.A. Babcock), Blackwell Publishing, Oxford, UK, pp. 87-94.

Stevens, J.D. 2010. Epipelagic oceanic elasmobranchs. In: Sharks and Their Relatives II: Biodiversity, Adaptative Physiology and Conservation (eds. J.C. Carrier, J.A. Musick and M.R. Heithaus). CRC Press, Boca Raton, FL (USA), pp. 3-36.

Stillwell, C.E., Kohler, N.E. 1982. Food, feeding habits, and estimates of daily ration in the shortfin mako (Isurus oxyrinchus) in the Northwest Atlantic. Canadian Journal of Fisheries and Aquatic Sciences 39, 407-414.

Thompson, D.R., Furness, R.W., Monteiro, L.R. 1998. Seabirds as biomonitors of mercury inputs to epipelagic and mesopelagic marine food chains. Science of the Total Environment 213, 299-305.

Vaudo, J.J., Heithaus, M.R. 2011. Dietary niche overlap in a nearshore elasmobranch mesopredator community. Marine Ecology Progress Series 425, 247-260.

Walker, B.H. 1992. Biodiversity and ecological redundancy. Conservation Biology 6, 18-23. 
Ward, P., Myers, R.A. 2005. Shifts in open-ocean fish communities coinciding with the commencement of commercial fishing. Ecology 86, 835-847.

Zar, J.H. 2009. Biostatistical analysis: International edition. Pearson Education.

Zeitzschel, B. 1969. Primary productivity in the Gulf of California. Marine Biology 3, 201-207. 
Table 1: Ecological characteristics ( ${ }^{*}$ minimal depth range, ${ }^{* *}$ major prey types) of pelagic shark species investigated in this study.

\begin{tabular}{|c|c|c|c|c|}
\hline Species & Habitat & $\begin{array}{l}\text { Depth range } \\
(\mathrm{m})^{*}\end{array}$ & Diet $^{\star *}$ & References \\
\hline Alopias pelagicus & Epipelagic, oceanic & $0-152$ & $\begin{array}{l}\text { Small- to medium sized fish } \\
\text { and squids }\end{array}$ & Compagno (1984), Smith et al. (2008) \\
\hline Carcharhinus falciformis & Epipelagic, oceanic & $0-500$ & $\begin{array}{l}\text { Large squids, pelagic fishes, } \\
\text { pelagic crabs }\end{array}$ & $\begin{array}{l}\text { Compagno (1984), Bonfil (2008), Cabrera-Chavez et } \\
\text { al. (2010) }\end{array}$ \\
\hline Carcharhinus longimanus & Epipelagic, oceanic & $0-152$ & $\begin{array}{l}\text { Large epipelagic teleosts and } \\
\text { squids }\end{array}$ & Compagno (1984), Bonfil et al. (2008) \\
\hline Prionace glauca & $\begin{array}{l}\text { Epi- to mesopelagic, } \\
\text { oceanic }\end{array}$ & $0-600$ & $\begin{array}{l}\text { Small pelagic fishes, squids } \\
\text { and elasmobranchs }\end{array}$ & Compagno (1984), Nakano and Stevens (2008) \\
\hline Isurus oxyrinchus & $\begin{array}{l}\text { Epi- to mesopelagic, } \\
\text { oceanic }\end{array}$ & $0-600$ & $\begin{array}{l}\text { Pelagic fishes, squids and } \\
\text { elasmobranchs }\end{array}$ & Stevens (2008) \\
\hline Pseudocarcharias kamoharai & Mesopelagic & $0-600$ & $\begin{array}{l}\text { Deep-water fishes, squids and } \\
\text { shrimps }\end{array}$ & Compagno (1984), Stevens (2010) \\
\hline Sphyrna lewini & $\begin{array}{l}\text { Coastal and semi- } \\
\text { oceanic }\end{array}$ & $0-450$ & $\begin{array}{l}\text { Pelagic to demersal fishes, } \\
\text { squids and elasmobranchs }\end{array}$ & $\begin{array}{l}\text { Compagno (1984), Kimley (1993), Hussey et al. } \\
\text { (2011) }\end{array}$ \\
\hline
\end{tabular}


Table 2: Characteristics of pelagic sharks sampled in the south-western Indian Ocean. Values are mean $( \pm \mathrm{SD})$. $\mathrm{TP}_{15 \mathrm{~N}}=\operatorname{trophic}$ position based on Hussey et al. (2014a and 2014b).

\begin{tabular}{|c|c|c|c|c|c|c|c|c|c|}
\hline \multirow[t]{2}{*}{ Species } & \multirow[t]{2}{*}{$n$} & \multicolumn{2}{|c|}{ Fork Length (cm) } & \multirow{2}{*}{$\begin{array}{l}\text { Sex ratio } \\
\qquad(m: f)\end{array}$} & \multirow{2}{*}{$\begin{array}{c}\delta^{15} \mathrm{~N}(\%) \\
\text { Mean } \pm \text { SD }\end{array}$} & \multirow{2}{*}{$\begin{array}{c}\delta^{13} \mathrm{C}(\%) \\
\text { Mean } \pm \text { SD }\end{array}$} & \multirow{2}{*}{$\begin{array}{c}\mathrm{C}: \mathrm{N} \\
\text { Mean } \pm \mathrm{SD}\end{array}$} & \multirow{2}{*}{$\begin{array}{l}\mathrm{Hg}\left(\mu \mathrm{g} \cdot \mathrm{g}^{-1} \mathrm{dw}\right) \\
\text { Mean } \pm \mathrm{SD}\end{array}$} & \multirow{2}{*}{$\begin{array}{c}\mathrm{TP}_{15 \mathrm{~N}} \\
\text { Mean } \pm \mathrm{SD}\end{array}$} \\
\hline & & Mean & Range & & & & & & \\
\hline Alopias pelagicus & 5 & 200 & $147-268$ & $1: 0$ & $13.91 \pm 0.69$ & $-16.71 \pm 0.43$ & $2.9 \pm 0.02$ & $4.97 \pm 3.60$ & $\begin{array}{c}4.4 \pm 0.3 \\
(3.9-4.7)\end{array}$ \\
\hline Carcharhinus falciformis & 3 & 114 & $96-148$ & $2: 1$ & $12.35 \pm 0.36$ & $-16.53 \pm 0.35$ & $2.9 \pm 0.1$ & $2.43 \pm 2.15$ & $\begin{array}{c}3.8 \pm 0.1 \\
(3.7-3.9)\end{array}$ \\
\hline Carcharhinus longimanus & 13 & 161 & $99-229$ & $0.2: 1$ & $13.39 \pm 1.03$ & $-16.46 \pm 0.44$ & $2.9 \pm 0.1$ & $7.14 \pm 7.44$ & $\begin{array}{c}4.2 \pm 0.4 \\
(3.5-4.7)\end{array}$ \\
\hline Prionace glauca & 31 & 202 & $160-269$ & $1: 0.8$ & $13.57 \pm 1.10$ & $-17.47 \pm 0.49$ & $2.8 \pm 0.2$ & $5.30 \pm 2.17$ & $\begin{array}{c}4.2 \pm 0.4 \\
(3.6-5.0)\end{array}$ \\
\hline Isurus oxyrinchus & 29 & 185 & $122-304$ & $0.8: 1$ & $14.62 \pm 0.68$ & $-16.74 \pm 0.58$ & $2.9 \pm 0.1$ & $5.96 \pm 2.78$ & $\begin{array}{c}4.7 \pm 0.3 \\
(3.9-5.3)\end{array}$ \\
\hline Pseudocarcharias kamoharai & 5 & 87 & $82-95$ & $1: 0.7$ & $14.35 \pm 0.57$ & $-16.58 \pm 0.57$ & $2.9 \pm 0.1$ & $17.25 \pm 6.45$ & $\begin{array}{c}4.5 \pm 0.2 \\
(4.3-4.8)\end{array}$ \\
\hline Sphyrna lewini & 6 & 152 & $100-190$ & $0.5: 1$ & $13.88 \pm 1.01$ & $-16.12 \pm 0.69$ & $3.0 \pm 0.1$ & $5.86 \pm 2.73$ & $\begin{array}{c}4.4 \pm 0.4 \\
(3.9-5.0)\end{array}$ \\
\hline
\end{tabular}


Table 3: Mean differences and p-values based on post hoc tests Tukey's tests for paired comparisons of Hg concentrations (top), $\delta^{15} \mathrm{~N}$ (middle), and $\delta^{13} \mathrm{C}$ (bottom). Significant differences are in bold.

\begin{tabular}{|c|c|c|c|c|c|c|}
\hline & A. pelagicus & C. falciformis & C. longimanus & I. oxyrinchus & P. glauca & P. kamoharai \\
\hline \multicolumn{7}{|l|}{$\log \mathrm{Hg}$} \\
\hline C. falciformis & $-0.701,0.612$ & & & & & \\
\hline I. oxyrinchus & $0.368,0.824$ & $1.069,<0.05$ & $0.122,0.995$ & & & \\
\hline P. glauca & $0.274,0.970$ & $0.946,0.090$ & $-0.0004,0.999$ & $-0.122,0.995$ & & \\
\hline P. kamoharai & $1.443,<0.01$ & $2.143,<0.001$ & $1.197,<0.01$ & $1.075,<0.01$ & $1.197,<0.001$ & \\
\hline \multicolumn{7}{|l|}{$\delta^{15} \mathrm{~N}$} \\
\hline C. falciformis & $-1.561,0.243$ & & & & & \\
\hline C. longimanus & $-0.523,0.931$ & $1.037,0.576$ & & & & \\
\hline I. oxyrinchus & $0.710,0.684$ & $2.271,<0.01$ & $1.233,<0.01$ & & & \\
\hline P. glauca & $-0.340,0.987$ & $1.221,0.307$ & $0.183,0.997$ & $-1.050,<0.001$ & & \\
\hline C. longimanus & $0.244,0.973$ & $0.068,0.999$ & & & & \\
\hline I. oxyrinchus & $-0.035,0.999$ & $-0.210,0.994$ & $-0.278,0.676$ & & & \\
\hline P. glauca & $-0.765,<0.05$ & $-0.940,0.052$ & $-1.009,<0.001$ & $-0.730,<0.001$ & & \\
\hline P. kamoharai & $0.126,0.999$ & $-0.049,0.999$ & $-0.118,0.999$ & $0.161,0.995$ & $0.891,<0.05$ & \\
\hline S. lewini & $0.585,0.508$ & $0.410,0.920$ & $0.342,0.833$ & $0.620,0.119$ & $1.350,<0.001$ & $0.459,0.765$ \\
\hline
\end{tabular}


Table 4: Percentage of $\delta^{13} \mathrm{C}$ vs. $\delta^{15} \mathrm{~N}$ overlap of corrected standard ellipses (SEAc) among the six species investigated; note two overlap values per species comparison are given, e.g. I. oxyrinchus vs. C. longimanus and vice versa.

\begin{tabular}{|c|c|c|c|c|c|c|}
\hline Species & C. longimanus & I. oxyrinchus & P. glauca & P. kamoharai & S. lewini & A. pelagicus \\
\hline C. longimanus & * & 23.9 & 1.8 & 62.5 & 38.6 & 65.7 \\
\hline I. oxyrinchus & 15.4 & * & 5.7 & 83.4 & 16.9 & 32.0 \\
\hline P. glauca & 2.9 & 1.4 & * & 0 & 1.5 & 8.7 \\
\hline P. kamoharai & 11.3 & 23.5 & 0 & * & 8.5 & 17.2 \\
\hline S. lewini & 71.1 & 48.4 & 1.7 & 87.0 & * & 64.7 \\
\hline A. pelagicus & 54.1 & 41 & 4.5 & 78.2 & 28.9 & * \\
\hline
\end{tabular}

Table 5: Percentage of $\mathrm{Hg}$ vs. $\delta^{13} \mathrm{C}$ overlap of corrected standard ellipses (SEAc) among the six species investigated; note two overlap values per species comparison are given, e.g. I. oxyrinchus vs. C. longimanus and vice versa.

\begin{tabular}{|c|c|c|c|c|c|c|}
\hline Species & C. longimanus & I. oxyrinchus & P. glauca & P. kamoharai & S. lewini & A. pelagicus \\
\hline C. longimanus & * & 68.3 & 8.1 & 34.7 & 59.8 & 75.9 \\
\hline I. oxyrinchus & 29.3 & * & 25.8 & 2 & 39.3 & 69.6 \\
\hline P. glauca & 1.8 & 13.1 & * & 0 & 1.4 & 1.5 \\
\hline P. kamoharai & 10.0 & 1.4 & 0 & * & 1.1 & 2.7 \\
\hline S. lewini & 29.0 & 44.4 & 3.1 & 1.8 & * & 20.5 \\
\hline A. pelagicus & 26.0 & 55.7 & 2.4 & 3.2 & 14.5 & * \\
\hline
\end{tabular}


Table 6: Percentage of $\mathrm{Hg}$ vs. $\delta^{15} \mathrm{~N}$ overlap of corrected standard ellipses (SEAc) among the six species investigated; note two overlap values per species comparison are given, e.g. I. oxyrinchus vs. C. longimanus and vice versa.

\begin{tabular}{|c|c|c|c|c|c|c|}
\hline Species & C. longimanus & I. oxyrinchus & P. glauca & P. kamoharai & S. lewini & A. pelagicus \\
\hline C. longimanus & * & 36.4 & 63.6 & 6.3 & 82.4 & 91.1 \\
\hline I. oxyrinchus & 8.1 & * & 33.2 & 6.6 & 38.2 & 28 \\
\hline P. glauca & 21.7 & 50.6 & * & 1.2 & 56.7 & 44.9 \\
\hline P. kamoharai & 3.3 & 1.6 & 1.9 & * & 7.6 & 6.4 \\
\hline S. lewini & 32.4 & 67.2 & 65.4 & 5.7 & * & 77.9 \\
\hline A. pelagicus & 34.1 & 46.9 & 49.3 & 4.5 & 74.2 & * \\
\hline
\end{tabular}

Table 7: Correlations between $\delta^{13} \mathrm{C}, \delta^{15} \mathrm{~N}$ values and $\log \mathrm{Hg}$ concentrations of pelagic sharks based on Pearson's correlations. Significant values are bold.

\begin{tabular}{|c|c|c|c|c|c|c|}
\hline \multirow{2}{*}{$\begin{array}{l}\text { Pearson } \\
\text { Species }\end{array}$} & \multicolumn{2}{|c|}{$\log H g / \delta^{15} \mathrm{~N}$} & \multicolumn{2}{|c|}{ Log $\mathrm{Hg} / \delta^{13} \mathrm{C}$} & \multicolumn{2}{|c|}{$\delta^{15} \mathrm{~N} / \delta^{13} \mathrm{C}$} \\
\hline & $t, p$-value & $r$ & $\mathrm{t}, \mathrm{p}$-value & $r$ & $\mathrm{t}, \mathrm{p}$-value & $r$ \\
\hline A. pelagicus & $-0.79,0.49$ & -0.41 & $2.67,0.08$ & 0.84 & $-0.35,0.75$ & -0.20 \\
\hline C. falciformis & $1.61,0.35$ & 0.85 & $-1.77,0.33$ & -0.87 & $-25.06,<0.05$ & 0.99 \\
\hline C. longimanus & $1.86,0.09$ & 0.49 & $-0.47,0.65$ & -0.14 & $1.71,0.11$ & 0.46 \\
\hline I. oxyrinchus & $0.32,0.75$ & 0.06 & $0.28,0.78$ & 0.05 & $4.67,>0.001$ & 0.67 \\
\hline P. glauca & $4.49,<0.001$ & 0.64 & $5.37,<0.001$ & 0.71 & $5.43,<0.001$ & 0.71 \\
\hline P. kamoharai & $0.97,0.40$ & 0.49 & $-1.13,0.34$ & -0.55 & $-1.50,0.23$ & -0.65 \\
\hline S. lewini & $0.15,0.89$ & 0.07 & $-1.39,0.24$ & -0.57 & $0.19,0.86$ & 0.10 \\
\hline All species & $3.84,<0.001$ & 0.38 & $1.11,0.27$ & 0.12 & $4.27,<0.001$ & 0.41 \\
\hline
\end{tabular}




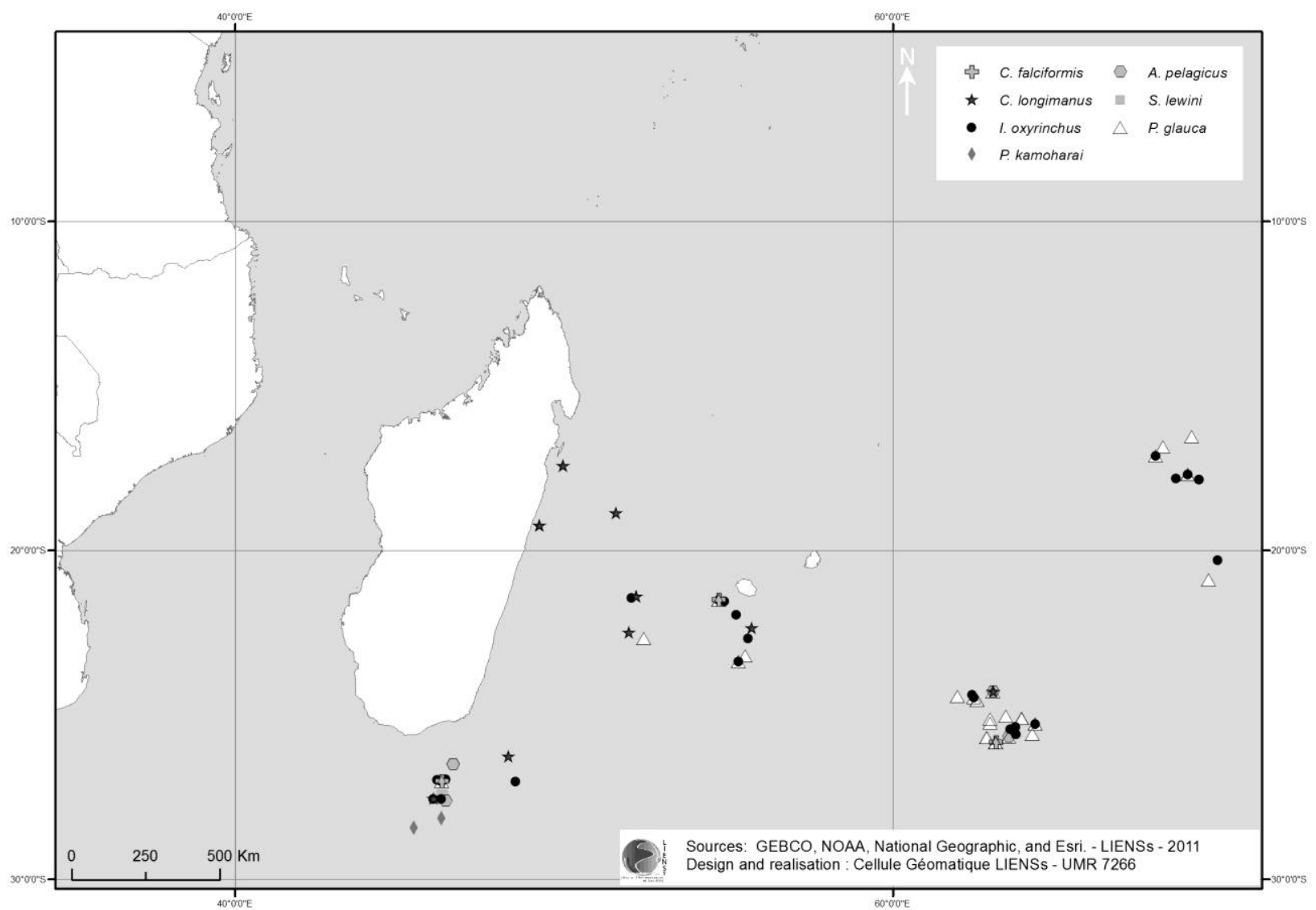

Fig. 1. Distribution of sampled oceanic sharks in the south-western Indian Ocean $(n=92)$. 


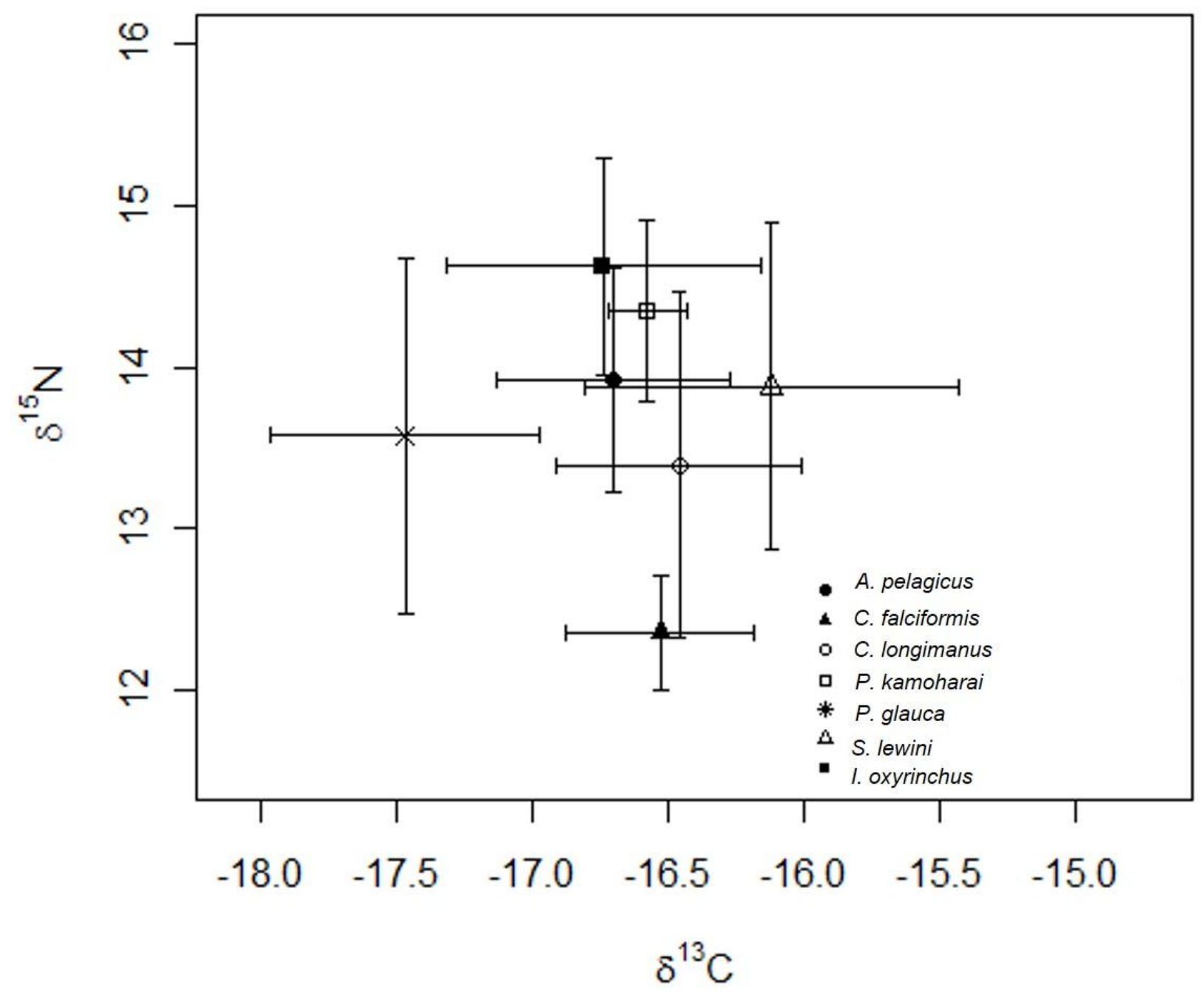

Fig. 2. Relationship (means $\pm \mathrm{SD}$ ) between $\delta^{15} \mathrm{~N}$ and $\delta^{13} \mathrm{C}$ values (\%o) of muscle. 


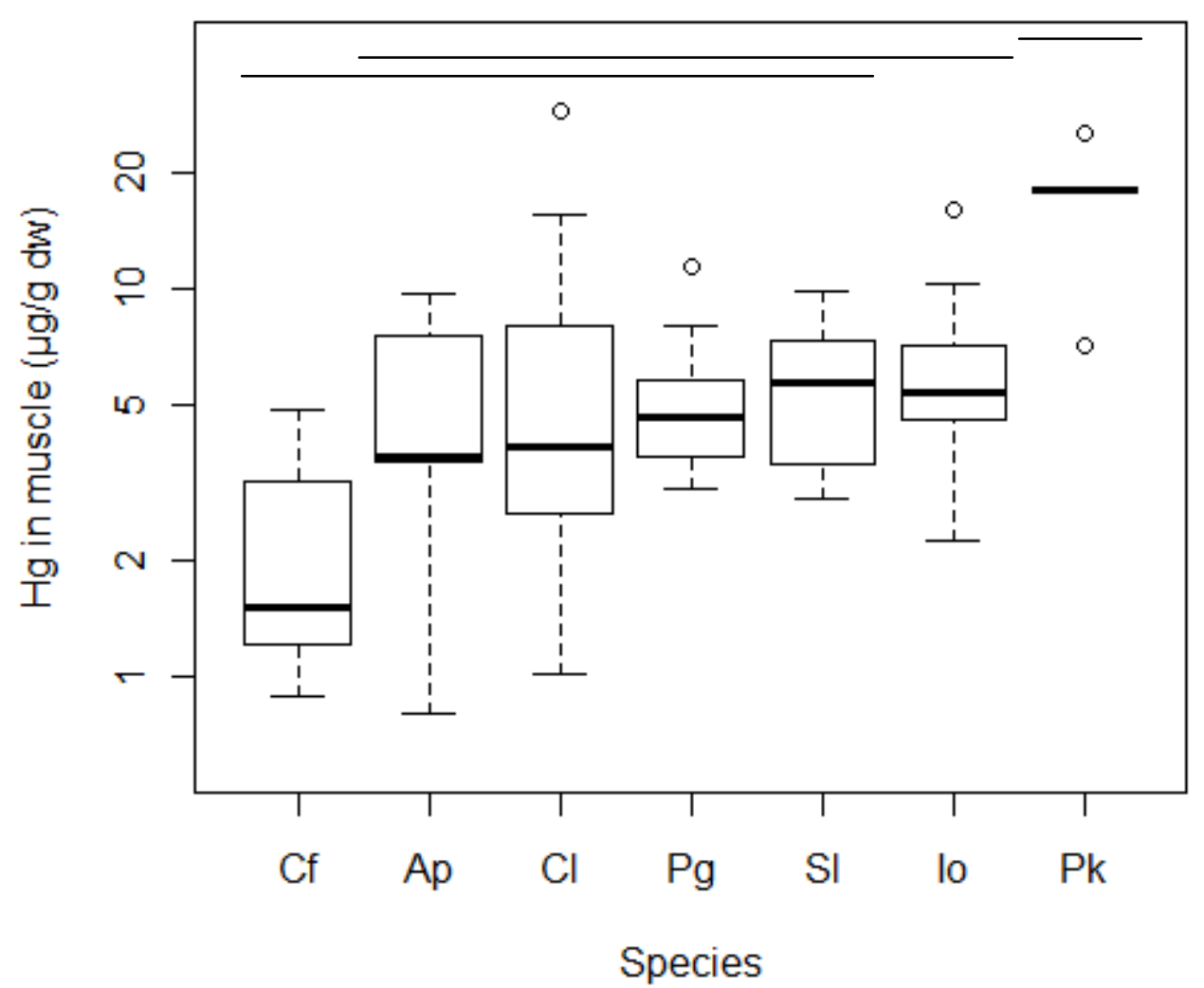

Fig. 3. Comparisons of $\mathrm{Hg}$ concentrations in muscle (in $\mu \mathrm{g} . \mathrm{g}^{-1} \mathrm{dw}$ ) of C. falciformis $(\mathrm{Cf})$, A. pelagicus (Ap), C. longimanus (Cl), P. glauca $(\mathrm{Pg})$, S. lewini $(\mathrm{Sl})$, I. oxyrinchus (Io) and P. kamoharai (Pk). The upper and lower hinges represent the quartiles, the vertical lines, the maximum and minimum data values and the bold line represents the median value while the points are outliers. Horizontal lines represent homogeneous groups determined by Tukey HSD (Honestly Significant Difference) test. 


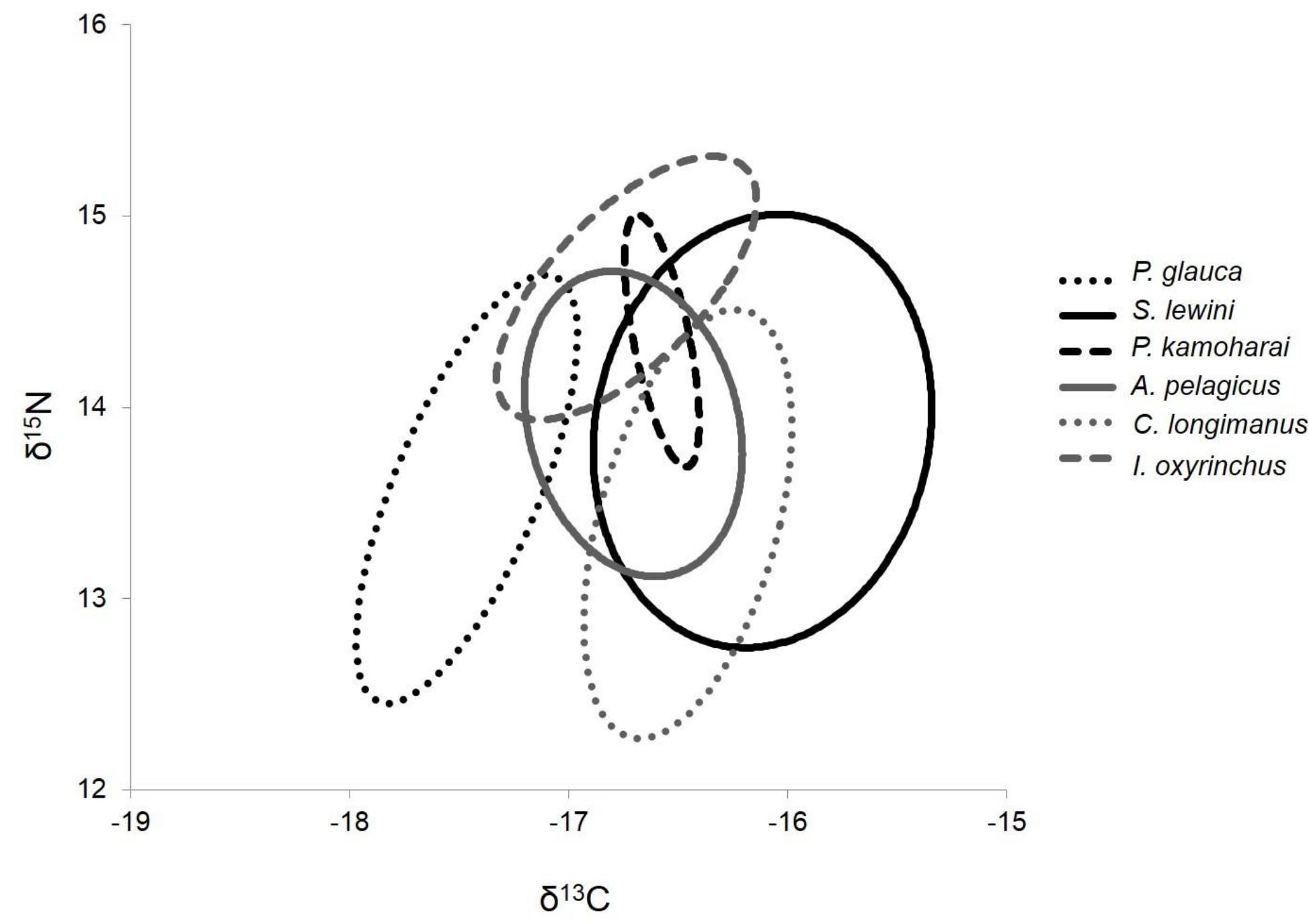

Fig. 4. Standard ellipses for corrected sample sizes (SEAc, in $\%$, $\delta^{15} \mathrm{~N}$ and $\delta^{13} \mathrm{C}$ ) of A. pelagicus, C. longimanus, P. glauca, S. lewini, I. oxyrinchus and $P$. kamoharai. 


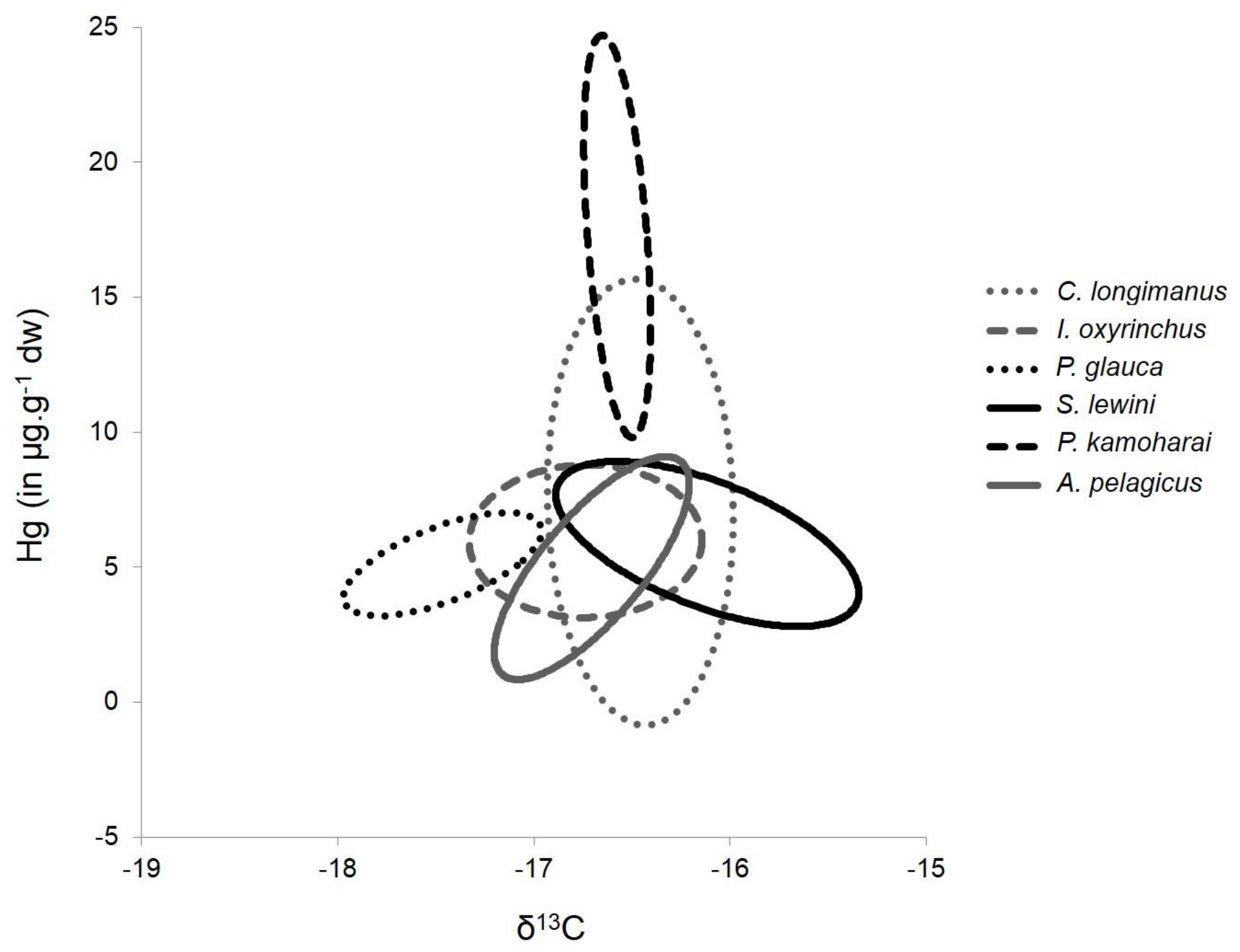

Fig. 5. Standard ellipses for corrected sample sizes (SEAc, in $\%$, $\delta^{13} \mathrm{C}$ ) and $\mathrm{Hg}$ concentrations (in $\mu \mathrm{g} . \mathrm{g}^{-1} \mathrm{dw}$ ) of A. pelagicus, C. longimanus, P. glauca, S. lewini, I. oxyrinchus and P. kamoharai. 


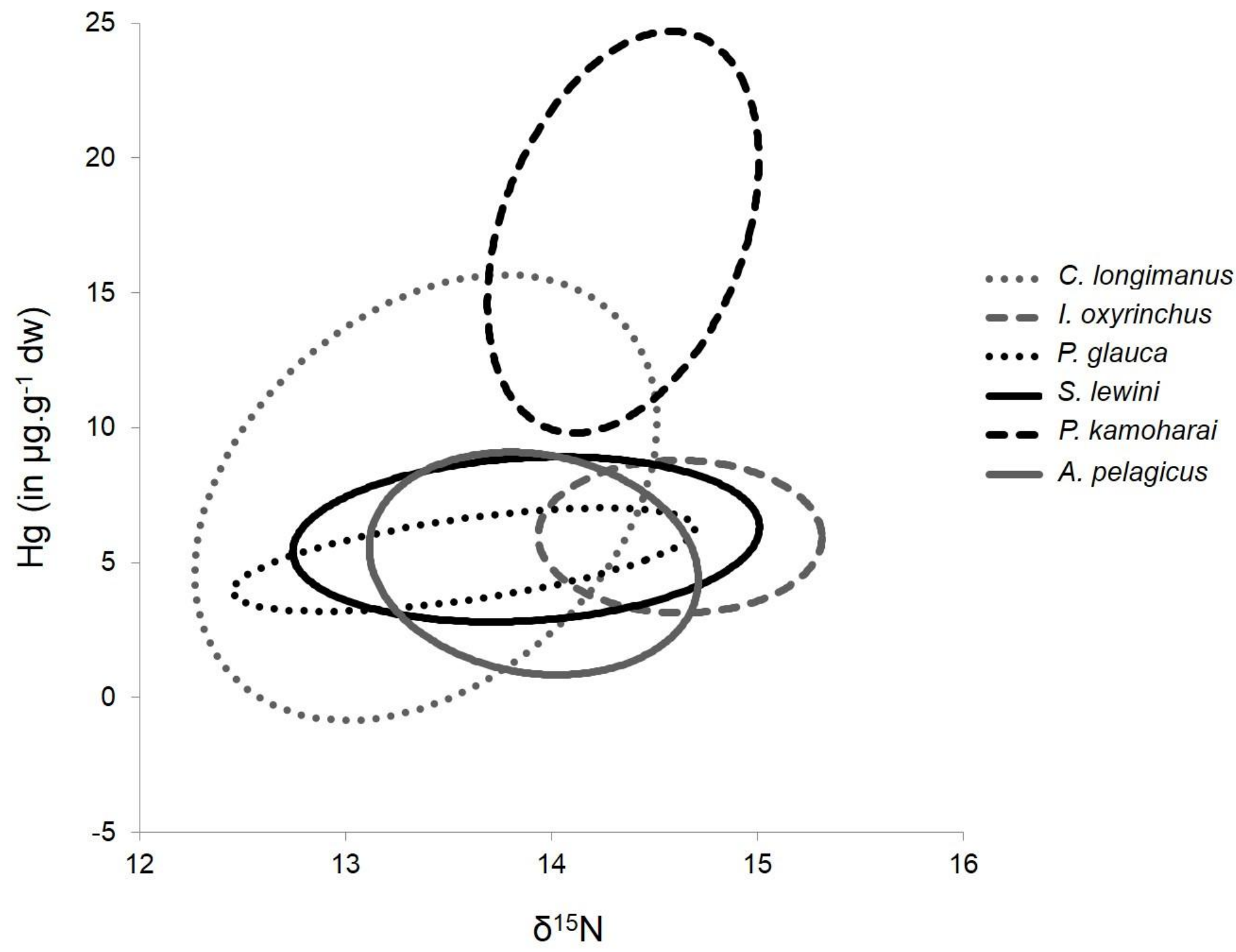

Fig. 6. Standard ellipses for corrected sample sizes (SEAc, in $\%$ o, $\delta^{15} \mathrm{~N}$ ) and $\mathrm{Hg}$ concentrations (in $\mu \mathrm{g} . \mathrm{g}^{-1} \mathrm{dw}$ ) of $A$. pelagicus, $C$. longimanus, $P$. glauca, S. lewini, I. oxyrinchus and P. kamoharai. 
I. oxyrinchus
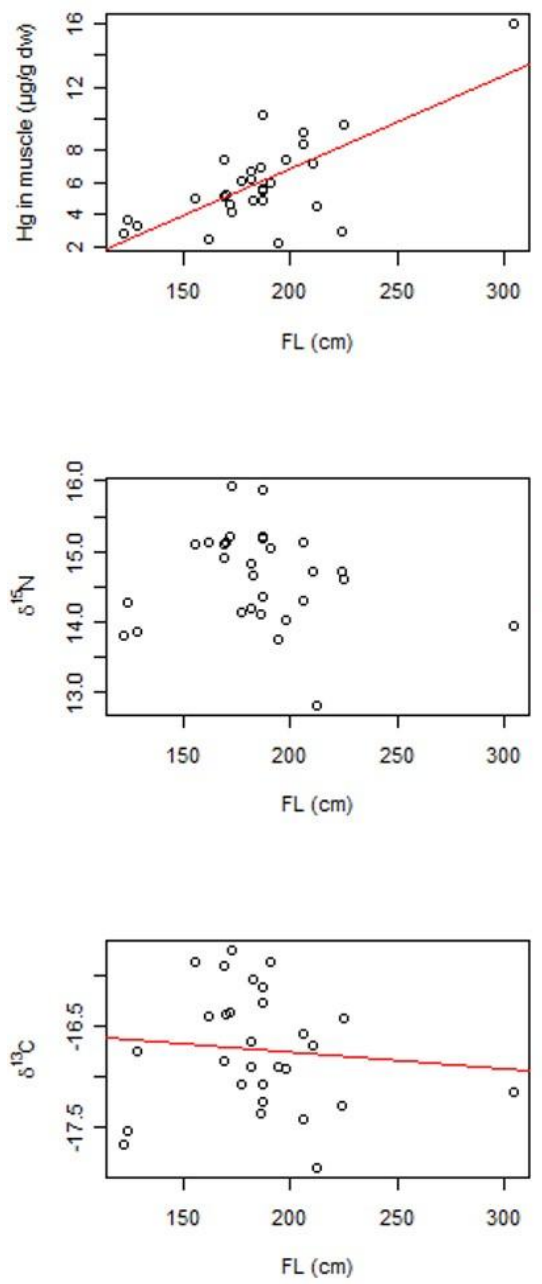

P. glauca
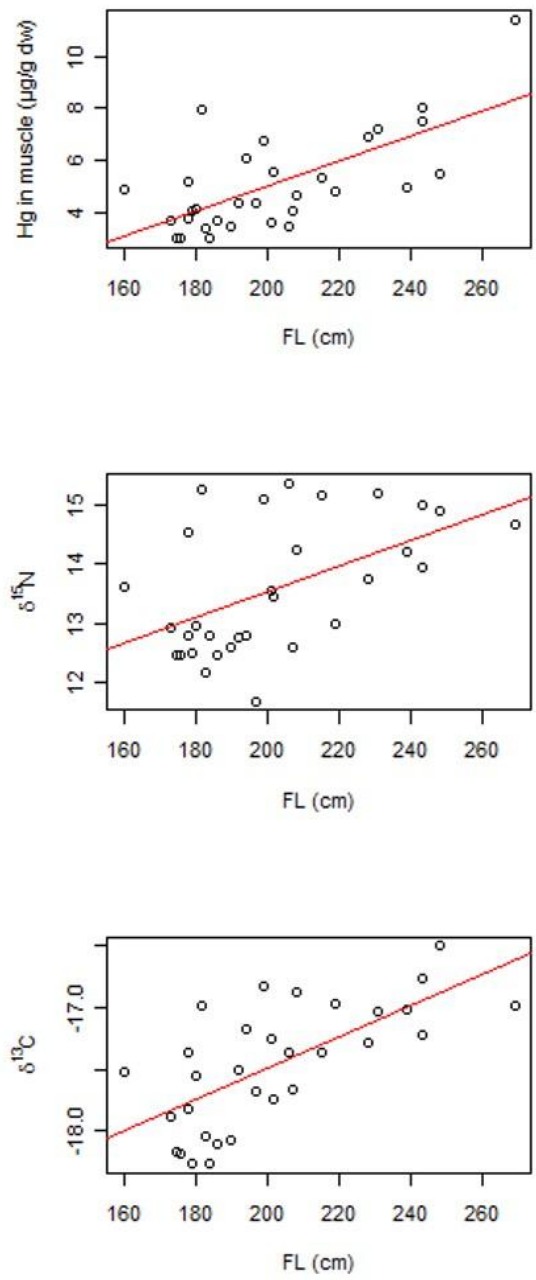

C. longimanus
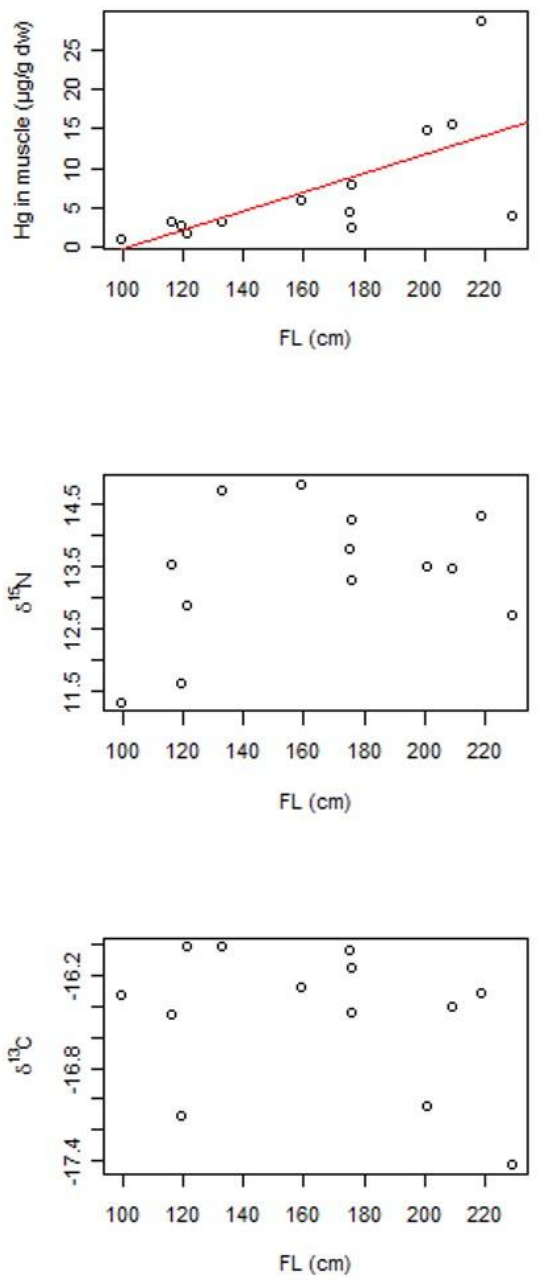

Fig. 7. Influence of size (FL: fork length) on $\log \mathrm{Hg}$ concentrations (top), $\delta^{15} \mathrm{~N}$ (middle) and $\delta^{13} \mathrm{C}$ values (bottom) in a- I. oxyrinchus, b- P. glauca and c- C. longimanus. 